\title{
The Prognostic Impact of Hormonal Receptor and HER-2 Expression Discordance in Metastatic Breast Cancer Patients
}

This article was published in the following Dove Press journal: OncoTargets and Therapy

\section{Ziyan Yang (D) ${ }^{1, *}$ \\ Nani Li $\mathbb{( D}^{2, *}$ \\ Xiaolin $\mathrm{Li}^{3}$ \\ Lei Lei $\mathbb{D D}^{3}$ \\ Xiaojia Wang $^{3}$}

'The Second Clinical Medical College of Zhejiang Chinese Medical University, Hangzhou, Zhejiang 310022, People's Republic of China;; ${ }^{2}$ Department of Medical Oncology, Fujian Cancer Hospital, Fuzhou, Fujian 3500I4, People's Republic of China; ${ }^{3}$ Department of Medical Oncology, Cancer Hospital of the University of Chinese Academy of Sciences, Hangzhou, Zhejiang, People's Republic of China

*These authors contributed equally to this work
Correspondence: Xiaojia Wang Department of Medical Oncology, Cancer Hospital of the University of Chinese Academy of Sciences, Hangzhou, Zhejiang 310022, People's Republic of China Tel +8613906500190

Email wxiaojia0803@I63.com
Background: Hormone receptor (HR) and human epidermal growth factor receptor (HER2) discordance between primary and metastatic breast cancer lesions is common. However, its impact on long-term survival remains unclear. We aimed to determine the prognostic value of this discordance in patients with metastaticf breast cancer (MBC).

Methods: A total of 270 patients with MBC who were underwent re-biopsy of progressive metastases at Zhejiang Cancer Hospital from January 1, 2012 to December 31, 2015 with patients consent and then review their primary tumors pathological findings. The HR and HER2 status in both primary and progressive metastatic lesions was determined by immunohistochemistry and/or fluorescence in situ hybridization. The discordance rates were correlated with the clinicopathologic characteristics, metastatic lesions, salvage treatment, and survival analysis in this population.

Results: A total of $142(52.6 \%)$ MBC patients were diagnosed with discordant HR and HER2 status. Alterations in estrogen receptor (ER), progesterone receptor (PR), and HER2 status were observed in $20.70 \%, 37.78 \%$, and $11.48 \%$ cases, respectively. Chemotherapy $(\mathrm{P}=0.0192)$ and endocrine therapy $(\mathrm{P}=0.048)$ significantly affected the conversion of HR status. Endocrine therapy was positively correlated with $\mathrm{PR}$ discordance $(\mathrm{P}=0.002)$, while $\mathrm{ER}$ discordance was associated with adjuvant chemotherapy $(\mathrm{P}=0.031)$. Survival analysis showed that ER status alterations between primary and metastatic lesions were associated with overall survival $(\mathrm{P}=0.002)$. The clinical prognosis was significantly worse with $\mathrm{HR}$ losses than with persistent HR positivity $(\mathrm{P}=0.023)$. In Cox multivariate analysis, the loss of HR expression and conversion to triple negative were independent prognostic indicators.

Conclusion: Discordance in HR status between primary and metastatic lesions may impact the prognosis of $\mathrm{MBC}$, and $\mathrm{HR}$ conversion has independent prognostic value.

Keywords: breast cancer, hormone receptor, receptor discordance, recurrent

\section{Introduction}

According to the World Cancer Report, 2012 published by the World Health Organization, ${ }^{1}$ breast cancer is the second most prevalent cancer worldwide and ranks first among women (GLOBOCAN 2012).

Genetically, breast cancer displays a high level of heterogeneity. The inherent heterogeneity of tumors and the variation of its evolution may lead to inconsistencies in molecular typing between primary and metastatic lesions. ${ }^{2}$ Therefore, knowledge of the molecular features is important for the development of therapeutic and prognostic strategies in breast cancer. 
Hormone therapy and targeted therapy is recommended for tumors expressing hormone receptors (HRs) and human epidermal growth factor receptor (HER2), and receptor status are potentially a key factor in predicting the prognosis of breast cancer. The progesterone receptor (PR) and estrogen receptor (ER) are key tissue markers that guide the treatment of breast cancer. Knowledge of these markers is essential during adjuvant treatment and for assessment of metastases. Previous investigations have suggested the presence of immunohistochemical changes in the expression of HR and HER2 between metastatic and primary tumors. ${ }^{3}$ In this study, the changes in HR and HER2 status were assessed in relation to clinicopathological features and treatment variables. We aimed to demonstrate the discordance rates and identify independent prognostic markers.

\section{Materials and Methods}

This study retrospectively obtained the data of 340 patients with MBC who were underwent re-biopsy of progressive metastases at Zhejiang Cancer Hospital from January 1, 2012 to December 31, 2015 with patients consent and then review their primary tumors pathological findings (the Bioethics Committee of Cancer Hospital of the University of Chinese Academy of Sciences approved this study). Among them, 270 were selected for analysis. Exclusion criteria: there were 5 cases of breast cancer in the past, but this time biopsy for other tumors, 18 cases of bilateral breast cancer, 5 cases of metastases detected only by HER-2/fluorescence in situ hybridization (FISH), and 42 cases with incomplete information of primary lesions. Inclusion criteria: all patients underwent biopsy of the recurrent metastatic lesions after treatment. and the 11 cases whose primary cancer was metastatic were assessed after one or several lines of treatment. Data with complete clinical and pathological characteristics, including age at diagnosis, tumor biology, tumor size, surgical intervention, chemotherapy, radiotherapy, targeted therapy, endocrine therapy, location of recurrent diseases, time before recurrence and immunohistochemical analysis of the findings in metastasis.

On the basis of tumor biology, the following groups were considered: intraductal carcinoma, invasive duct carcinoma, invasive lobular carcinoma, medullary carcinoma, and other rare types. Tumor size and lymph node status were classified according to the TNM classification (Joint American Cancer Commission, 7th edition). Surgical interventions include breast conserving or modified radical surgery. Endocrine therapy includes the following drugs: tamoxifen (TAM), aromatase inhibitor (AI) with GnRH analogues, TAM with GnRH analogues, TAM with AI and $\mathrm{GnRH}$ analogues, TAM with GnRH analogues only and without treatment.

On immunohistochemistry (IHC), ER and PR were considered positive when $\geq 1 \%$ of tumor cells showed significant staining. Changes in receptor expression between the primary tumor and metastatic lesions were analyzed using the Chisquare's test. The SPSS v 25.0 (IBM Corp. Released 2017. IBM SPSS Statistics for Windows, Version 25.0. Armonk, NY: IBM Corp.) statistical software package was used to calculate the correlation between changes in HR and HER2 and clinicopathological features and previous treatment for the disease. The cumulative survival rate of events was calculated from the survival curves using the Kaplan-Meier approach, and comparisons between curves were determined using the logarithmic rank test. The multivariate Cox proportional hazards regression model was used to determine the independent prognostic factors for OS (overall survival).

\section{Results}

\section{Patient Characteristics}

The clinical features of the 270 patients have been shown in Table 1 . Most of the patients were primarily diagnosed with a pT1 $(21.85 \%)$ or pT2 (40.37\%) tumor. Histological diagnoses comprised invasive duct carcinomas (80.74\%), lobular carcinomas (6.67\%), and others (12.59\%); $92.59 \%(\mathrm{n}=250)$ and $2.22 \%(\mathrm{n}=6)$ underwent modified radical and breastconserving surgery, respectively. Overall, 139 (51.48\%) patients received endocrine therapy; 91 (33.70\%) received TAM or GnRH monotherapy $(\mathrm{n}=1 ; 0.37 \%)$, while several different adjuvant endocrine therapies were prescribed for the remaining 47 patients. A total of 236 (87.41\%), 110 (40.74\%), and 11 (4.07\%) women received chemotherapy, radiotherapy, and targeted therapy, respectively. In this cohort, 136 (50.37\%), 127 (47.04\%), and 7 (2.59\%) patients had metastases to the lymph nodes, soft tissue, and bones, the viscera, and the brain, respectively (Table 1).

\section{Correlation Between Hormone Receptor Changes and Therapies}

The status of the three receptors was determined using tissue samples from the metastatic lesions; the correlations between receptor expression discordance (later vs basal) and different therapeutic methods were then analyzed. The discordance in ER, PR, and HER2 expression during metastasis has been presented in Table 2 . The primary tumors stained positive for ER, PR, and HER2 in 183, 159, and 96 patients, respectively. 
Table I Clinical Characteristics and Therapy $(n=270)$

\begin{tabular}{|c|c|c|c|}
\hline \multicolumn{2}{|c|}{ Clinicopathological Factors } & \multirow{2}{*}{$\begin{array}{l}\begin{array}{l}\text { Mean } \\
\text { (Range) }\end{array} \\
46.5(24-7\end{array}$} & \multirow{2}{*}{$\begin{array}{l}\text { Frequency } \\
(\%) \\
)\end{array}$} \\
\hline Age (years) & & & \\
\hline T-stage & $\begin{array}{l}\text { pTI } \\
\text { pT2 } \\
\text { pT3 } \\
\text { pT4 } \\
\text { pTx }\end{array}$ & $\begin{array}{l}59 \\
109 \\
27 \\
12 \\
63\end{array}$ & $\begin{array}{l}21.85 \% \\
40.37 \% \\
10.00 \% \\
4.45 \% \\
23.33 \%\end{array}$ \\
\hline $\mathrm{N}$-stage & $\begin{array}{l}\mathrm{p} N 0 \\
\mathrm{pNI} \\
\mathrm{pN} 2 \\
\mathrm{p} N 3 \\
\mathrm{p} N x\end{array}$ & $\begin{array}{l}77 \\
51 \\
56 \\
72 \\
14\end{array}$ & $\begin{array}{l}28.52 \% \\
18.89 \% \\
20.74 \% \\
26.67 \% \\
5.18 \%\end{array}$ \\
\hline M-stage & $\begin{array}{l}\text { pMO } \\
\text { PMI } \\
\text { PMx }\end{array}$ & $\begin{array}{l}257 \\
11 \\
2\end{array}$ & $\begin{array}{l}95.19 \% \\
4.07 \% \\
0.74 \%\end{array}$ \\
\hline Pathology & $\begin{array}{l}\text { Intraductal carcinoma } \\
\text { Invasive Duct } \\
\text { carcinoma } \\
\text { Invasive lobular carcinoma } \\
\text { Medullary carcinoma } \\
\text { Rare types carcinoma }\end{array}$ & $\begin{array}{l}7 \\
218 \\
18 \\
3 \\
24\end{array}$ & $\begin{array}{l}2.59 \% \\
80.74 \% \\
\\
6.67 \% \\
1.11 \% \\
8.89 \%\end{array}$ \\
\hline Surgery & $\begin{array}{l}\text { No } \\
\text { Modified radical } \\
\text { operation } \\
\text { Breast-conserving } \\
\text { surgery } \\
\text { Not sure }\end{array}$ & $\begin{array}{l}12 \\
250 \\
6 \\
2\end{array}$ & $\begin{array}{l}4.44 \% \\
92.59 \% \\
2.22 \% \\
0.74 \%\end{array}$ \\
\hline Chemotherapy & $\begin{array}{l}\text { No } \\
\text { Yes }\end{array}$ & $\begin{array}{l}34 \\
236\end{array}$ & $\begin{array}{l}12.59 \% \\
87.41 \%\end{array}$ \\
\hline Radiotherapy & $\begin{array}{l}\text { No } \\
\text { Yes }\end{array}$ & $\begin{array}{l}160 \\
110\end{array}$ & $\begin{array}{l}59.25 \% \\
40.74 \%\end{array}$ \\
\hline $\begin{array}{l}\text { Endocrine } \\
\text { therapy }\end{array}$ & $\begin{array}{l}\text { No } \\
\text { Tamoxifen } \\
\text { Aromatase inhibitor } \pm \\
\text { GnRH } \\
\text { Tamoxifen }+ \text { GnRH } \\
\text { Aromatase inhibitor } \\
+ \text { tamoxifen } \pm \text { GnRH } \\
\text { GnRH mono }\end{array}$ & $\begin{array}{l}131 \\
91 \\
34 \\
5 \\
8 \\
1\end{array}$ & $\begin{array}{l}54.13 \% \\
33.70 \% \\
12.59 \% \\
\\
1.85 \% \\
2.96 \% \\
0.37 \%\end{array}$ \\
\hline $\begin{array}{l}\text { Trastuzumab } \\
\text { therapy }\end{array}$ & $\begin{array}{l}\text { No } \\
\text { Yes }\end{array}$ & $\begin{array}{l}259 \\
11\end{array}$ & $\begin{array}{l}95.93 \% \\
4.07 \%\end{array}$ \\
\hline Metastasis & $\begin{array}{l}\text { Lymph nodes, soft tissue, } \\
\text { and bone } \\
\text { Viscus } \\
\text { Brain }\end{array}$ & $\begin{array}{l}136 \\
127 \\
7\end{array}$ & $\begin{array}{l}50.37 \% \\
47.04 \% \\
2.59 \%\end{array}$ \\
\hline
\end{tabular}

Abbreviations: $T$, primary tumor size; $N$, regional lymph node; $M$, distant metastasis, $\mathrm{pT}$, pathological tumor; $\mathrm{pN}$, pathological node; $\mathrm{pM}$, pathological metastasis; $\mathrm{GnRH}$, Gonadotropin-Releasing Hormone.
Table 2 ER, PR and HER2 Expression Conversion During Metastasis

\begin{tabular}{|l|l|l|l|}
\hline & Receptor Status & Cases & Percentage \\
\hline ER & + to - & 40 & $14.81 \%$ \\
& - to + & 16 & $5.93 \%$ \\
& + & 143 & $52.96 \%$ \\
& - & 71 & $21.3 \%$ \\
& Concordance & 214 & $79.25 \%$ \\
& Discordance & 56 & $20.70 \%$ \\
\hline \multirow{5}{*}{ PR } & + to - & 72 & $26.67 \%$ \\
& - to + & 30 & $11.11 \%$ \\
& + & 87 & $32.22 \%$ \\
& - & 81 & $30.00 \%$ \\
& Concordance & 168 & $62.22 \%$ \\
& Discordance & 102 & $37.78 \%$ \\
\hline \multirow{5}{*}{ HER2 } & + to - & 11 & $4.07 \%$ \\
& - to + & 20 & $7.41 \%$ \\
& + & 63 & $23.33 \%$ \\
& - & 126 & $46.67 \%$ \\
& Concordance & 189 & $70.00 \%$ \\
& Discordance & 31 & $11.48 \%$ \\
& - to not sure & 28 & $10.37 \%$ \\
& + to not sure & 22 & $8.15 \%$ \\
\hline
\end{tabular}

Notes: Frequencies of receptor changes between primary diagnosis and recurrent disease are shown for estrogen receptor (ER), progesterone receptor $(\mathrm{PgR})$ and HER2 receptor. + to -, loss in expression; - to +, gains in expression; +, Persistent positivity; -, Persistent negativity.

The corresponding numbers in the recurrent metastatic lesions were 159,117 , and 83, respectively. HER2 expression was undetermined in 50 recurrent metastatic samples, and FISH was not performed for economic reasons. Receptor discordance (with conversion in the expression of any receptor) for ER, PR, and HER2 was observed in 56, 102, and 31 cases, respectively. Positive-to-negative alterations in ER, PR, and HER2 occurred in $14.81 \%, 26.67 \%$, and $4.07 \%$ patients, respectively; the corresponding negative-to-positive conversion rates were $5.93 \%, 11.11 \%$, and $7.41 \%$, respectively. The numbers of patients in the four subtypes based on the HR and HER2 status in the primary lesion were as follows: $\mathrm{HR}^{+}$/ $\mathrm{HER}^{-}$type $(\mathrm{n}=131), \mathrm{HR}^{+} / \mathrm{HER} 2^{+}$type $(\mathrm{n}=61), \mathrm{HR}^{-} /$ $\mathrm{HER}^{+}$type (HER2 type) $(\mathrm{n}=36)$, and $\mathrm{HR}^{-} / \mathrm{HER}^{-}$type (triple-negative [TN]) $(n=42)$ (Table 3$)$. Overall, 28 patients were found to have no changes in the ER and PR status, and their HER2 status was uncertain. Compared with gains in HR expression, more patients with recurrent lesions experienced HR loss; a triple positive to negative conversion was observed in 2 cases. In addition, the gain of HER2 expression was more common than loss.

Chemotherapy $(\mathrm{P}=0.0192)$ and endocrine therapy $(\mathrm{P}=0.048)$ were found to be important factors affecting 
Table 3 Comparison of Tumor Subtype Between Primary and Recurrent Tumors

\begin{tabular}{|c|c|c|c|c|c|c|c|}
\hline & \multicolumn{6}{|c|}{ HR, HER2 Status in Metastasis Sites } & \multirow[t]{2}{*}{ Total } \\
\hline & HR+/HER2- & HR+/HER2+ & HR-/HER2+ & HR-IHER2- & $\begin{array}{l}\text { HR-/HER2 } \\
\text { Not Sure }\end{array}$ & $\begin{array}{l}\text { HR+/HER2 } \\
\text { Not Sure }\end{array}$ & \\
\hline \multicolumn{8}{|c|}{$\begin{array}{l}\text { HR, HER2 status in } \\
\text { primary sites }\end{array}$} \\
\hline $\mathrm{HR}+/ \mathrm{HER} 2-$ & $77(28.5)$ & II (4.I) & $2(0.7)$ & $15(5.6)$ & $5(1.9)$ & $21(7.8)$ & $|3|(48.5)$ \\
\hline $\mathrm{HR}+/ \mathrm{HER} 2+$ & $5(1.9)$ & $32(11.9)$ & $10(3.7)$ & $2(2.9)$ & $2(2.9)$ & $10(3.7)$ & $61(22.6)$ \\
\hline HR-/HER2+ & $0(0)$ & $5(1.9)$ & $16(6)$ & $5(1.9)$ & $4(1.5)$ & $6(2.2)$ & $36(13.3)$ \\
\hline HR-/HER2- & $13(4.8)$ & $3(1.1)$ & $4(1.5)$ & $20(7.4)$ & $2(0.7)$ & $0(0)$ & $42(15.5)$ \\
\hline Total & $95(35.2)$ & $51(18.9)$ & $32(11.9)$ & $42(15.6)$ & $13(4.8)$ & $37(13.7)$ & 270 \\
\hline
\end{tabular}

Note: -, Means receptor expression negative; +, Means receptor expression positive.

Abbreviations: HER2, human epidermal growth factor receptor 2; HR, hormone receptor.

the conversion of HR status, and adjuvant endocrine therapy correlated positively with $\mathrm{PR}$ discordance $(\mathrm{P}=0.006)$. ER discordance was found to be associated with the administration of chemotherapy ( $\mathrm{P}=0.031$ ); no relationship was observed between receptor discordance and metastatic lesions $(\mathrm{P}=0.653)$. Overall, the alterations in receptor expression may have been influenced by the treatment methods (Table 4). High risk of receptor alteration was observed in patients with low-grade and small primary tumors. But that's not important. There was no significant correlation between lymphatic metastasis status and any receptor changes $(\mathrm{P}=0.363)$. Patients who received different adjuvant endocrine therapy did not demonstrate a higher risk for receptor alterations during recurrence $(\mathrm{p}=0.336)$. We also assessed the association between surgical treatments for primary focus and receptor discordance in recurrent disease. Mastectomy was not associated with any receptor discordance. However, the different lines of salvage hormonal therapy are at higher risk of showing receptor changes in recurrent diseases $(\mathrm{P}<0.001)$. In 28 patients, we were unable to determine whether hormonal receptor changes had occurred because of the uncertain state of HER2 at the metastasis site, the unchanged ER and PR in primary and metastatic lesions, so they were excluded.

\section{Correlation Between Receptor Changes and Survival}

A total of 141 deaths were observed in this cohort, with a 1-, 3-, 5 -, and 10-year survival rate of $98.6 \%, 74.5 \%, 39.7 \%$, and $12.1 \%$, respectively. The median OS was 54 (95\% confidence interval $[\mathrm{CI}]=47.8-60.2)$ months. The OS, disease-free survival (DFS), and post-recurrence survival (PRS) were individually recorded (Table 5). In the four groups, namely, those with loss in expression, persistent negativity, persistent positivity, and gains in expression, the OS in the ER persistent negative and positive groups was shorter (median survival: 39 months) and longer (median survival: 60 months), respectively. Compared with the ER persistently positive group, the OS of the other three groups was significantly different $(\mathrm{P}=0.02)$; significant differences were also noted between those with loss in ER expression ( $\mathrm{P}=0.039)$. Moreover, the group of loss in ER has a worse impact on survival (Figure 1A). A significant difference was noted between the persistently PR positive and negative groups (Figure 1B); however, there was no significant difference between those with persistent PR positivity and loss in PR expression. The PR conversion status had no significant correlation with OS. Figure $1 \mathrm{C}$ shows the Kaplan-Meier OS curves of the four groups. The numbers of patients with alterations in each group were as follows: group 1: $\mathrm{HR}^{+} / \mathrm{HER} 2^{-/+}$to $\mathrm{HR}^{+} / \mathrm{HER} 2^{-/+}(\mathrm{n}=157)$, group $2: \mathrm{HR}^{+} /$ $\mathrm{HER}^{-/+}$to $\mathrm{HR}^{-} / \mathrm{HER}^{-/+}(\mathrm{n}=36)$, group $3: \mathrm{HR}^{-} / \mathrm{HER}^{-}$to $\mathrm{HR}^{-} / \mathrm{HER} 2^{-}(\mathrm{n}=22)$, and group $4: \mathrm{HR}^{-} / \mathrm{HER}^{-/+}$to $\mathrm{HR}^{+} /$ $\mathrm{HER}^{-/+}(\mathrm{n}=27)$. There were significant differences between groups 1 and $2(p<0.0001)$; however, there were no significant differences between groups 2, 3, and 4 ( $\mathrm{P}>0.05)$. Compared with losses in HR receptor expression, persistent HR positivity had a particularly significant impact on the prognosis of MBC; those with persistent HR negativity were found to be at particular risk of poor survival.

We performed Cox univariate and multivariate analyses for the clinicopathological features in 242 patients to evaluate the impact of the baseline factors on OS; those with uncertain HER2 status and missing data were excluded (Table 6). The risk of death increased with higher AJCC $\mathrm{T}$ stage, conferring a poor prognosis 
Table 4 Association Between the Change of ER, PR, and Her-2 Status and Clinicopathological Variables

\begin{tabular}{|c|c|c|c|c|c|c|c|}
\hline \multirow[t]{2}{*}{ Feature } & \multirow[t]{2}{*}{$\begin{array}{l}\text { No } \\
\text { Change }\end{array}$} & \multirow[t]{2}{*}{ Change } & \multicolumn{2}{|c|}{$\begin{array}{l}\text { Change in } \\
\text { Any Receptor }\end{array}$} & \multirow{2}{*}{$\begin{array}{l}\text { ER } \\
\text { Discordance } \\
\text { P value }\end{array}$} & \multirow{2}{*}{$\begin{array}{l}\text { PR } \\
\text { Discordance } \\
\text { P value }\end{array}$} & \multirow{2}{*}{$\begin{array}{l}\text { HER2 } \\
\text { Discordance } \\
\text { P value }\end{array}$} \\
\hline & & & \multicolumn{2}{|c|}{$\begin{array}{l}\text { Chi-Square } \\
\text { p value }\end{array}$} & & & \\
\hline T-stage $(n=242)$ & & & 5.778 & 0.216 & 0.728 & 0.106 & 0.746 \\
\hline pTI & $25(10.3)$ & $29(12.9)$ & & & $12(5.0)$ & $19(7.8)$ & $5(2.1)$ \\
\hline pT2 & $39(16.1)$ & $60(24.8)$ & & & $27(\mid I .2)$ & $44(18.2)$ & $15(6.2)$ \\
\hline pT3 & $6(2.5)$ & $18(7.4)$ & & & $4(I .6)$ & $13(5.4)$ & $4(1.6)$ \\
\hline pT4 & $6(2.5)$ & $3(1.2)$ & & & $2(0.8)$ & $I(0.4)$ & $0(0)$ \\
\hline pTx & $24(9.9)$ & $32(13.2)$ & & & $\mathrm{II}(4.5)$ & $25(10.3)$ & $6(2.5)$ \\
\hline$N$-stage $(n=242)$ & & & 4.325 & 0.363 & 0.170 & 0.922 & 0.974 \\
\hline $\mathrm{pNI}$ & $24(9.9)$ & $23(9.5)$ & & & $7(2.9)$ & $18(7.4)$ & $7(2.9)$ \\
\hline $\mathrm{pN} 2$ & $17(7.0)$ & $32(13.2)$ & & & $17(7.0)$ & $22(9.1)$ & $7(2.9)$ \\
\hline $\mathrm{pN} 3$ & $22(9.1)$ & $4 I(16.9)$ & & & $16(6.6)$ & $30(12.4)$ & $7(2.9)$ \\
\hline $\mathrm{pN} 4$ & $6(2.5)$ & $6(2.5)$ & & & $\mathrm{I}(0.4)$ & $5(2.1)$ & $\mathrm{I}(0.4)$ \\
\hline $\mathrm{pNx}$ & $3 I(\mid 2.8)$ & $40(16.5)$ & & & $15(6.2)$ & $27(|| .2)$ & $9(3.7)$ \\
\hline M-stage $(n=242)$ & & & 2.213 & 0.331 & 0.749 & 0.720 & 0.912 \\
\hline pMO & $95(39.3)$ & $138(57.0)$ & & & $54(22.3)$ & $98(40.5)$ & $30(12.4)$ \\
\hline pMI & $5(2.1)$ & $3(1.2)$ & & & $2(0.8)$ & $3(1.2)$ & $\mathrm{I}(0.4)$ \\
\hline pMx & $0(0)$ & $I(0.4)$ & & & $0(0)$ & $I(0.4)$ & $0(0)$ \\
\hline Surgery $(n=242)$ & & & 0.324 & 0.569 & 0.278 & 0.776 & 0.806 \\
\hline Yes & $95(39.3)$ & $137(56.6)$ & & & $55(22.7)$ & $97(40.1)$ & $28(11.6)$ \\
\hline Not & $5(2.1)$ & $5(2.1)$ & & & $\mathrm{I}(0.4)$ & $5(2.1)$ & $3(1.2)$ \\
\hline Radiotherapy $(n=242)$ & & & 0.248 & 0.618 & 0.331 & 0.164 & 0.886 \\
\hline Yes & $66(27.3)$ & $39(16.1)$ & & & $26(10.7)$ & $47(19.4)$ & $13(5.4)$ \\
\hline No & $91(37.6)$ & $47(19.4)$ & & & $30(12.4)$ & $55(22.7)$ & $18(7.4)$ \\
\hline Chemotherapy $(n=242)$ & & & 5.481 & 0.0192 & 0.031 & 0.259 & 0.258 \\
\hline Yes & $125(5 \mid .6)$ & $90(37.2)$ & & & $5 I(2 I . I)$ & $88(36.4)$ & $29(12.0)$ \\
\hline No & $22(9.1)$ & $5(2.1)$ & & & $4(1.6)$ & $14(5.8)$ & $2(0.8)$ \\
\hline Endocrine therapy $(n=242)$ & & & 3.9 & 0.048 & 0.877 & 0.002 & 0.850 \\
\hline Yes & $55(22.7)$ & $61(25.2)$ & & & $30(12.4)$ & $65(26.9)$ & $16(6.6)$ \\
\hline No & $44(18.2)$ & $82(33.9)$ & & & $27(\mid I .2)$ & $36(14.9)$ & $15(6.2)$ \\
\hline Trastuzumab therapy $(n=242)$ & & & 3.212 & 0.073 & 0.331 & 0.171 & 0.366 \\
\hline Yes & $7(2.9)$ & $3(1.2)$ & & & $\mathrm{I}(0.4)$ & $2(0.8)$ & $2(0.8)$ \\
\hline No & $96(39.7)$ & $136(56.2)$ & & & $55(22.7)$ & $100(41.3)$ & $29(12.0)$ \\
\hline Auxiliary endocrine therapy $(n=242)$ & & & 4.55 & 0.336 & 0.624 & 0.071 & 0.776 \\
\hline Untreated & $55(22.7)$ & $60(24.8)$ & & & $27(I I .2)$ & $36(14.9)$ & $15(6.2)$ \\
\hline Tamoxifen & $29(12.0)$ & $53(21.9)$ & & & $21(8.7)$ & $43(17.8)$ & $10(4.1)$ \\
\hline $\mathrm{Al} \pm \mathrm{GnRH}$ & $\mathrm{II}(4.5)$ & $21(8.7)$ & & & $8(3.3)$ & $15(6.2)$ & $2(0.8)$ \\
\hline $\mathrm{TAM}+\mathrm{GnRH}$ & $3(1.2)$ & $4(1.6)$ & & & $0(0)$ & $4(1.7)$ & $I(0.4)$ \\
\hline $\mathrm{Al}+\mathrm{TAM} \pm \mathrm{GnRH}$ & $\mathrm{I}(0.4)$ & $4(1.6)$ & & & $0(0)$ & $3(1.2)$ & $\mathrm{I}(0.4)$ \\
\hline GnRH mono & $\mathrm{I}(0.4)$ & $0(0)$ & & & $0(0)$ & $0(0)$ & $0(0)$ \\
\hline Metastasis & & & 0.853 & 0.653 & 0.189 & 0.136 & 0.390 \\
\hline Lymph nodes and bone & $49(20.2)$ & $74(30.6)$ & & & $31(12.8)$ & $53(21.9)$ & $14(5.8)$ \\
\hline Viscus & $49(20.2)$ & $63(26.0)$ & & & $22(9.1)$ & $44(18.2)$ & $17(7.0)$ \\
\hline Brain & $2(0.83)$ & $5(2.1)$ & & & $3(1.2)$ & $4(1.7)$ & $\mathrm{I}(0.4)$ \\
\hline
\end{tabular}


Table 4 (Continued).

\begin{tabular}{|c|c|c|c|c|c|c|c|}
\hline \multirow[t]{2}{*}{ Feature } & \multirow[t]{2}{*}{$\begin{array}{l}\text { No } \\
\text { Change }\end{array}$} & \multirow[t]{2}{*}{ Change } & \multicolumn{2}{|c|}{$\begin{array}{l}\text { Change in } \\
\text { Any Receptor }\end{array}$} & \multirow{2}{*}{$\begin{array}{l}\text { ER } \\
\text { Discordance } \\
\text { P value }\end{array}$} & \multirow{2}{*}{$\begin{array}{l}\text { PR } \\
\text { Discordance } \\
\text { P value }\end{array}$} & \multirow{2}{*}{$\begin{array}{l}\text { HER2 } \\
\text { Discordance } \\
\text { P value }\end{array}$} \\
\hline & & & \multicolumn{2}{|c|}{$\begin{array}{l}\text { Chi-Square } \\
\text { p value }\end{array}$} & & & \\
\hline Different lines of ET $(n=86)$ & & & 51.76 & 0.0001 & & & \\
\hline 0 & $80(93.0)$ & $6(7.0)$ & & & & & \\
\hline 1 & $42(17.3)$ & $44(18.1)$ & & & & & \\
\hline 2 & $70(28.9)$ & $16(6.6)$ & & & & & \\
\hline 3 & $77(31.8)$ & $9(3.7)$ & & & & & \\
\hline 4 & $80(33.0)$ & $6(2.5)$ & & & & & \\
\hline 5 & $85(35.1)$ & $I(0.4)$ & & & & & \\
\hline 6 & $84(34.7)$ & $2(0.8)$ & & & & & \\
\hline 7 & $84(34.7)$ & $2(0.8)$ & & & & & \\
\hline
\end{tabular}

Notes: Correlations between several diagnostic factors or adjuvant therapies and the occurrence of receptor changes were analyzed. Data was not fully $(n=270=100 \%)$ available for each factor but percentage according to $n=242=100 \%$ is displayed in brackets (Twenty-eight patients were unable to determine whether hormonal receptor changes occurred because of the uncertain state of Her2 at metastasis sites, so exclude).

Abbreviations: T, primary tumor size; N, regional lymph node; M, distant metastasis, pT, pathological tumor; pN, pathological node; pM, pathological metastasis. ATM, Tamoxifen; Al, Aromatase inhibitor.

Table 5 Influence of Receptor Conversion on Overall Survival, Disease-Free Survival, Post-Recurrence Survival

\begin{tabular}{|l|l|l|l|l|}
\hline & & OS Median & DFS Median & PRS Median \\
\hline ER & + to- & $50(24.72-75.28)$ & $40(3.44-76.57)$ & $44(26.1$ I-6I.89) \\
& - to+ & $56(40.50-71.50)$ & $58(10.53-105.47)$ & $43(20.63-65.37)$ \\
& - & $39(31.45-46.55)$ & $29(26.17-31.83)$ & $30(23.43-36.57)$ \\
& + & $60(54.5 I-65.49)$ & $72(50.24-93.76)$ & $56(50.96-61.04)$ \\
\hline PR & + to- & $56(48.27-63.73)$ & $56(20.55-91.45)$ & $54(39.77-68.23)$ \\
& - to+ & $39(29.20-48.80)$ & $27(0.00-72.56)$ & $28(18.02-37.98)$ \\
& - & $44(33.69-54.31)$ & $29(25.72-32.28)$ & $31(16.45-45.55)$ \\
& + & $77(49.39-104.60)$ & $73(54.09-91.90)$ & $57(43.79-70.21)$ \\
\hline HER2 & + to- & $62(36.34-87.66)$ & $34(18.14-49.86)$ & $40(28.56-51.44)$ \\
& - to+ & $33(12.60-53.40)$ & $95(53.37-90.89)$ & $92(52.34-87.88)$ \\
& - & $56(48.52-63.48)$ & $55(4 I .66-68.34)$ & $38(25.04-50.96)$ \\
& + & $43(24.21-61.79)$ & $54(21.56-86.44)$ & $55(28.16-81.84)$ \\
\hline
\end{tabular}

(hazard ratio: $1.38,95 \% \mathrm{CI}: 1.17-1.63, \mathrm{P}<0.0005$ ). Similarly, the mortality rate was higher in patients with metastases to lymph nodes (hazard ratio: $1.06,95 \% \mathrm{CI}$ : 1.01-1.12, $\mathrm{P}=0.017$ ) and distant sites (hazard ratio: 4.71 , 95\% CI: 2.07-11.11, $\mathrm{P}<0.0005)$. Compared to the $\mathrm{HR}^{+} /$ HER2 ${ }^{-}$tumors, the $\mathrm{HR}^{-} / \mathrm{HER} 2+$ tumors were associated with a higher risk of mortality (hazard ratio: $1.88,95 \%$ CI: $1.13-3.13, \mathrm{p}=0.0152)$; TNBC also conferred higher risk (hazard ratio: 3.29, 95\% CI: 2.04-5.28, $\mathrm{P}<0.0001$ ). Conversely, surgery(hazard ratio: $0.191,95 \% \mathrm{CI}$ : 0.083-0.44, $\mathrm{P}<0.0001$ ) and endocrine therapy(hazard ratio: $0.59,95 \% \mathrm{CI}: 0.43-0.83, \mathrm{P}<0.0005)$ reduced the risk of MBC-related mortality. As a systemic treatment, chemotherapy provided better survival for MBC; however, the impact on OS was not significant (hazard ratio: 0.65, 95\% CI: $0.42-1.02, \mathrm{P}=0.062$ ). Compared with persistent positive in $\mathrm{HR}$ expression $\left(\mathrm{HR}^{+} / \mathrm{HER} 2^{-/+}\right.$to $\mathrm{HR}^{+} /$ HER $\left.2^{-/+}\right)$, patients with recurrent lesions experienced $\mathrm{HR}$ loss $\left(\mathrm{HR}^{+} / \mathrm{HER}^{-/+}\right.$to $\left.\mathrm{HR}^{-} / \mathrm{HER}^{-/+}\right)$have higher risk (hazard ratio: $1.75,95 \% \mathrm{CI}: 1.01-3.03, \mathrm{P}=0.047$ ); The risk of $\mathrm{HR}^{-} / \mathrm{HER} 2^{-/+}$to $\mathrm{HR}^{-} / \mathrm{HER} 2^{-/+}$(hazard ratio: 3.21, 95\% CI: $1.74-5.90, \mathrm{P}=0.0002)$ was higher than patients with $\mathrm{HR}$ gain $\left(\mathrm{HR}^{-} / \mathrm{HER} 2^{-} \digamma^{+}\right.$to $\mathrm{HR}^{+} / \mathrm{HER} 2^{-/+}$) (hazard ratio: $2.79,95 \%$ CI: $1.62-4.83, \mathrm{P}=0.0002$ ).

Multivariate analysis included all prognostic factors that achieved significance on univariate analysis. In both, 

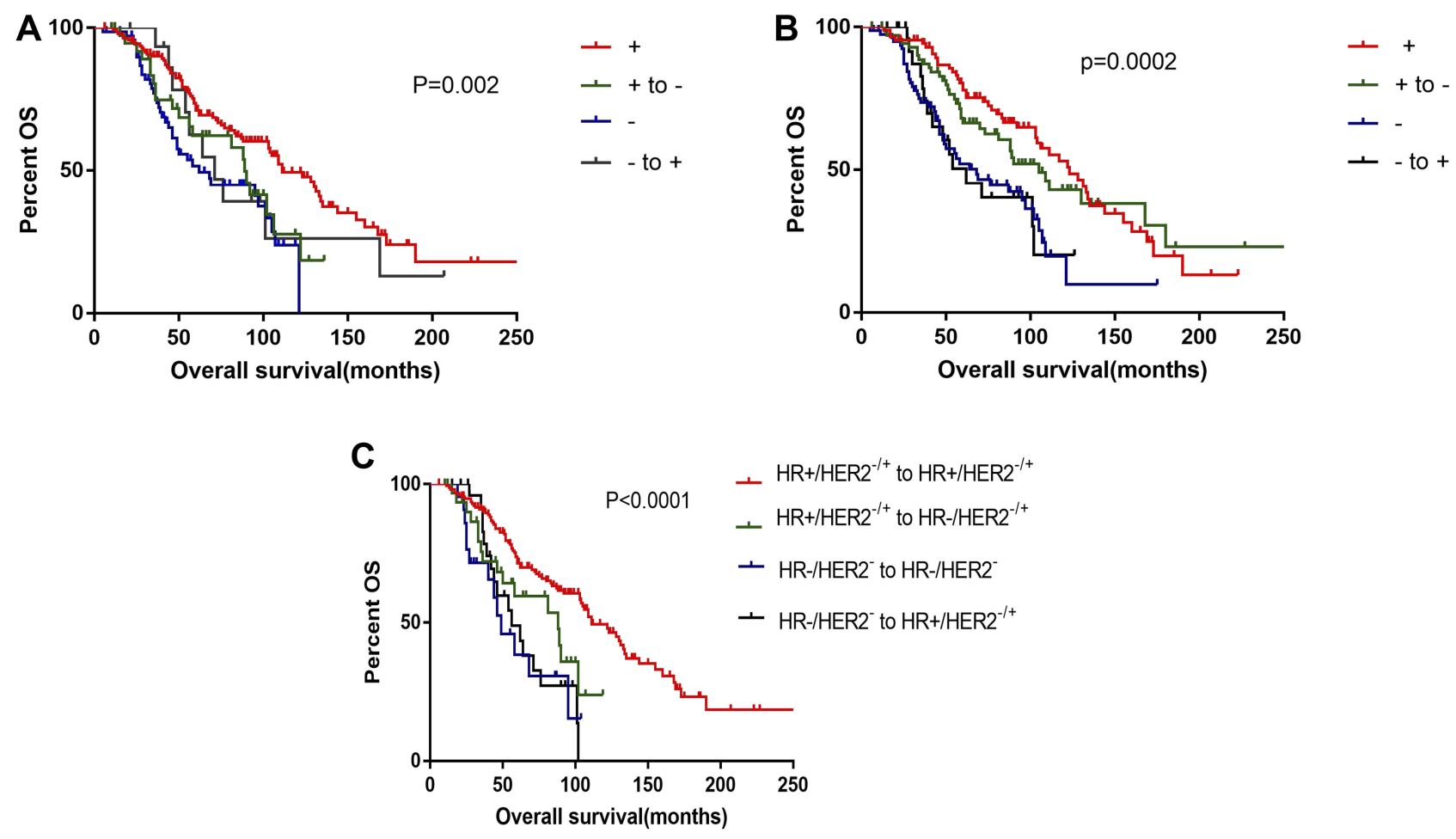

Figure I Overall survival. (A) +, ER persistent positivity; + to -, ER loss in expression; -, ER persistent negativity; - to +, ER gains in expression; (B) +, PR persistent positivity; + to -, PR loss in expression; -, PR persistent negativity; - to +, PR gains in expression; (C) Groupl, $\mathrm{HR}^{+} / \mathrm{HER}^{-/+}$to HR ${ }^{+} / \mathrm{HER}^{-/+}$; Group $2, \mathrm{HR}^{+} / \mathrm{HER}^{-/+}$to HR $/$ $\mathrm{HER}^{-/+}$; Group $3, \mathrm{HR}^{-} / \mathrm{HER} 2^{-}$to $\mathrm{HR}^{-} / \mathrm{HER} 2^{-}$; Group $4, \mathrm{HR}^{-} / \mathrm{HER} 2^{-/+}$to $\mathrm{HR}^{+} / \mathrm{HER}^{-1+}$.

HR loss was a significant and independent predictor of poorer clinical outcomes (hazard ratio: 1.78, 95\% CI: 1.02-3.1, $\mathrm{P}=0.0409$, on multivariate analysis). The risk of $\mathrm{HR}^{-} / \mathrm{HER} 2^{-/+}$to $\mathrm{HR}^{+} / \mathrm{HER} 2^{-/+}$conversion (hazard ratio: 2.48, 95\% CI: $1.41-4.37, \mathrm{p}=0.0016$ ) was lower than that of $\mathrm{HR}^{-} / \mathrm{HER}^{-}$to $\mathrm{TNBC}$ (hazard ratio: $2.98,95 \% \mathrm{CI}$ : 1.61-5.55, $\mathrm{p}=0.0005)$; however, the difference was not significant. Therefore, conversion from $\mathrm{HR}^{+}$in primary tumors to $\mathrm{HR}^{-}$in recurrent tumors was a significant and independent indicator of poorer clinical outcomes; the different treatment options also influenced survival.

\section{Discussion}

In this study, the discordance rates between metastatic lesions and primary tumors for ER, PR, and HER2 receptor were $20.70 \%, 37.78 \%$, and $11.48 \%$, respectively. The conversions were mainly losses in ER and PR expression, while the majority of HER2 conversions were gains. Overall, the discordance rates (and discordance-rate orders of the three receptors) observed in this study were similar to those in previous reports; ${ }^{4-6}$ as frequently reported, losses of receptor expression exceeded the gains. ${ }^{7,8}$ According to most studies, PR has the highest discordance rate, followed by ER and HER2. Few reports have suggested that HER2 ranks second and ER third. ${ }^{9}$ In terms of receptor discordance, our major findings suggested that adjuvant endocrine therapy positively correlates with PR discordance, and ER discordance is associated with chemotherapy. Additionally, persistent ER negativity conferred poorer survival. The conversion of HR appeared to have a significant impact on survival. Although we conclude that HER2 conversion has no effect on survival, most of our patients did not receive targeted therapy; thus, we could not conclude that HER2 conversion had an impact on survival. This demonstrated that patients with tumors that were ER-/PR- and HER2- had the worst prognosis. Multivariate analysis showed that HR loss was a significant and independent predictor of poorer clinical outcomes.

Changes in receptor profile between primary and metastatic lesions have been widely studied. ${ }^{10}$ In general, ER or PR losses represent a therapeutic challenge in breast cancer. The development and progress of breast cancer are regulated by many hormones. ER is a key HR, and its positivity indicates a highly differentiated tumor with relatively low malignant behavior; these patients may respond to endocrine treatment and have a good prognosis. PR is a downstream effector of ER signals; with the ER status 
Table 6 Univariate and Multivariate Analysis Between Clinicopathological Characteristics and OS of Breast Cancer Patients

\begin{tabular}{|c|c|c|c|c|}
\hline & \multicolumn{2}{|c|}{ Univariate Analysis } & \multicolumn{2}{|c|}{ Multivariate Analysis } \\
\hline & HR (95\% Cl) & P-value & HR (95\% Cl) & P-value \\
\hline \multicolumn{5}{|l|}{ Age } \\
\hline$\leq 45$ & Reference & - & Reference & - \\
\hline$>45$ & $1.52(1.08-2.13)$ & 0.0151 & $1.58(1.12-2.23)$ & 0.0096 \\
\hline$T$ stage $(0 / 1 / 2 / 3 / 4)$ & $1.38(1.17-1.63)$ & $<0.0005$ & $1.21(1.03-1.42)$ & 0.0244 \\
\hline \multicolumn{5}{|l|}{ Axillary lymph node } \\
\hline Negative & Reference & & Reference & \\
\hline Positive & $1.06(1.01-1.12)$ & 0.017 & - & \\
\hline \multicolumn{5}{|l|}{ Molecular subtype } \\
\hline HR+/HER2- & Reference & - & Reference & \\
\hline $\mathrm{HR}+/ \mathrm{HER} 2+$ & $1.38(0.89-2.15)$ & 0.1483 & - & - \\
\hline HR-/HER2+ & $1.88(1.13-3.13)$ & 0.0152 & - & - \\
\hline TNBC & $3.29(2.04-5.28)$ & $<0.0001$ & $2.67 \mid(1.7-4.198)$ & $<0.0001$ \\
\hline \multicolumn{5}{|l|}{ Distant metastasis } \\
\hline No & Reference & & Reference & \\
\hline Yes & $4.71(2.07-11.11)$ & $<0.0005$ & $6.16(2.54-14.92)$ & $<0.0001$ \\
\hline \multicolumn{5}{|l|}{ Surgery } \\
\hline No & reference & & reference & \\
\hline Yes & $0.191(0.083-0.44)$ & $<0.0001$ & $0.59(0.50-0.69)$ & $<0.0001$ \\
\hline \multicolumn{5}{|l|}{ Chemotherapy } \\
\hline No & Reference & & Reference & \\
\hline Yes & $0.65(0.42-1.02)$ & 0.0622 & - & - \\
\hline Radiation & & & - & - \\
\hline No & Reference & & Reference & - \\
\hline Yes & $1.62(1.13-2.33)$ & 0.0089 & $1.66(1.17-2.36)$ & 0.0461 \\
\hline \multicolumn{5}{|l|}{ Endocrine therapy } \\
\hline No & Reference & & Reference & - \\
\hline Yes & $0.59(0.43-0.83)$ & $<0.0005$ & - & - \\
\hline \multicolumn{5}{|l|}{ HR change } \\
\hline $\mathrm{HR}+/ \mathrm{HER} 2-^{1+}$ to $\mathrm{HR}+/ \mathrm{HER} 2-^{1+}$ & Reference & - & Reference & - \\
\hline $\mathrm{HR}+/ \mathrm{HER} 2-^{1+}$ to HR-/HER2 $-^{1+}$ & $1.75(1.01-3.03)$ & 0.047 & $1.78(1.02-3.1)$ & 0.0409 \\
\hline HR-/HER2 - to HR-/HER2- & $3.21(1.74-5.90)$ & 0.0002 & $2.98(1.6 \mathrm{I}-5.55)$ & 0.0005 \\
\hline HR $-/$ HER2 ${ }^{\prime /+}$ to HR+/HER2 ${ }^{-{ }^{\prime+}}$ & $2.79(1.62-4.83)$ & 0.0002 & $2.48(I .4 I-4.37)$ & 0.0016 \\
\hline
\end{tabular}

Notes: +, Means receptor expression positive; -, Means receptor expression negative.

Abbreviations: HER2, human epidermal growth factor receptor 2; HR, hormone receptor.

unaltered, PR status may change in specific cases owing to the presence of other additional signaling pathways. In our cohort, ER and PR showed similar trends in conversion, with loss of expression in most discordant cases. In other studies, changes in PR status were most common, followed by changes in ER and less frequently, HER2 (usually gain of HER2 amplification). ${ }^{11}$ However, the discordance rates for HER2 were not significant in previous reports. ${ }^{1}$ We noticed a relatively lower discordance rate for
HER2, which agreed with the findings of certain studies. ${ }^{12}$ Nevertheless, the findings suggested that HER2 may have a high discordance rate and act as a reference. The proportion of discordant marker status in the primary and metastatic lymph nodes was $3.4 \%$ for both HER 2 and Topo2a. ${ }^{13}$ Overall, the findings from different studies are inconsistent; this has also been reported in a metaanalysis. ${ }^{14}$ Further investigation is needed to identify the underlying mechanisms. 
Discordance in receptor status may be attributed to either changes in receptor expression or to errors in receptor assessment. ${ }^{15}$ Intra-tumoral biomarker heterogeneity may impact the classification of breast cancer, causing apparent receptor discordance. However, based on some accurate techniques (including mRNA assessment), Italian researchers found that heterogeneity is not likely to cause discordance. ${ }^{16}$ In cases of accurate receptor assays, discordance is generally believed to be driven by tumor progression/trans-differentiation owing to therapy-related stress. Certain reports suggest that poor survival in discordant cases may be related to the inappropriate use of targeted therapies; ${ }^{12}$ an Indian study has also suggested that ER/PR status may change after chemotherapy and that re-evaluation is needed after chemotherapy. ${ }^{17}$ In a study, all anti-estrogen-treated tumors lost ER expression, particularly in cases involving brain metastases. ${ }^{18}$ In this study, we demonstrated for the first time that adjuvant endocrine therapy and chemotherapy may alter PR and ER receptor profiles. Similar studies have suggested that in ER- and HER2-positive patients, endocrine therapy and trastuzumab treatment are independent factors associated with discordance. ${ }^{19}$ Reports also suggest that chemotherapy may alter ER, PR, and HER2 status. ${ }^{20}$

Certain pertinent observations may be made regarding survival and receptor discordance. Discordance in receptor status has been regarded to have prognostic implications. For instance, PR at relapse and Ki-67 in the primary tumor are significant factors for post-relapse prognosis, while PR loss has been reported to be a poor prognostic factor. ${ }^{21}$ In particular, cases involving conversions to triple-negative types show the poorest outcomes. ${ }^{3}$ Matsumoto et $\mathrm{al}^{22}$ reported that patients with hormonal receptors had turned positive in metastatic lesions have better survival. In our study, we found that the persistent lack of ER and PR expression had the worst prognostic impact on OS. The survival rate was worse with the loss of ER expression than with persistent ER positive expression. But there is no significant difference in the loss of PR compare with persistent positive. Patients with ER discordance had better OS; this was regarded to be the result of chemotherapy. In 2014, a Turkish study with a small sample size suggested that ER discordance was an independent prognostic factor for PFS. ${ }^{20}$ However, in their study, no independent prognostic factors were found for both OS and DFS on multivariate analysis. In contrast, conversion of HR positivity in the primary tumor to HR negativity in the recurrent tumor was an independent indicator of poorer clinical outcomes in our Cox univariate and multivariate analyses. In the study by Chan et al, multivariate analysis showed that HR and bcl-2 losses were significantly associated with a worse clinical outcome. ${ }^{23}$ Meanwhile, based on Cox univariate and multivariate analyses, the loss of $\mathrm{HR}$ expression and conversion to TNBC at the recurrence site can be independent prognostic factors for recurrent breast cancer. ${ }^{24}$ This is consistent with our results.

In cases of weakening expression of receptors (particularly ER and PR), the scope for prediction of outcomes using these three receptors is limited, and additional markers may be used for assessing progression, i.e., Ki6 $7^{25}$ and conversion of PD L1, ${ }^{26}$ among others. Overall, there are considerable discordance between different studies. In addition to the mechanisms of discordance, further investigation is needed to explore the impact of receptor status conversion on patient outcomes and the clinical management of these cases.

According to the latest guidelines of the American Society of Clinical Oncology (ASCO), ${ }^{27}$ it is recommended that treatment should be guided by recurrent ER/ PR/HER2 status when feasible. Provide biopsy and optimize treatment strategy for patients with recurrence and metastasis. The limitations of our study include the relatively small sample size for studying HER 2 conversion. In theory, discordance may also be guided by the metastatic lesion. For instance, HER2 loss occurs more frequently in lymph node metastases beyond the axilla. ${ }^{28}$ We did not observe a clear relationship between the metastatic lesion and receptor conversion; this may be because our sample size was not sufficiently large. Further studies on cumulative data are needed for confirmation.

\section{Conclusion}

In summary, the results of this study reveal that the expression of three receptors could be significantly discordant between primary breast tumors and associated metastatic lesions in different styles. Biomarker discordance can be impacted by therapeutic methods and have prognostic roles in OS.

\section{Ethical Approval and Informed Consent}

The Bioethics Committee of Cancer Hospital of the University of Chinese Academy of Sciences approved this study. Participants were in accordance with the ethical standards of the institutional research committee (Bioethics 
Committee of Cancer Hospital of the University of Chinese Academy of Sciences). Informed consent was obtained from all individual participants included in the study.

\section{Acknowledgment}

We would like to thank Editage for English language editing.

\section{Author Contributions}

All authors made substantial contributions to the design and conception of the study, and acquisition, analysis and interpretation of data, and took part in either drafting or revising the manuscript. All authors gave final approval of the version to be published and agreed to be accountable for all aspects of the work in ensuring that questions related to the accuracy or integrity of any part of the work are appropriately investigated and resolved.

\section{Funding}

This study was funded by the National Natural Science Foundation of China (Grant Number: 81672597), the National Clinical Key Specialty Construction Program, Fujian Natural Science Foundation (grant number 2018J 0105, 13181509), and Training Project of Young Talents in Fujian Health System (grant number 2015-ZQN-JC-6).

\section{Disclosure}

The authors declare that they have no conflict of interest in this work.

\section{References}

1. Goldhirsch A, Ingle JN, Gelber RD, Coates AS, Thürlimann B, Senn HJ. Panel members: thresholds for therapies: highlights of the St Gallen International Expert Consensus on the primary therapy of early breast cancer 2009. Ann Oncol. 2009;20(8):1319-1329. doi:10.1093/annonc/mdp322

2. Amir E, Clemons M, Purdie CA, et al. Tissure confirmation of disease recurrence in breast cancer patients: pooled analysis of multi-centre, multi disciplinary prospective studies. Cancer Treat Rev. 2012;38:708-714. doi:10.1016/j.ctrv.2011.11.006

3. Dieci MV, Barbieri E, Piacentini F, et al. Discordance in receptor status between primary and recurrent breast cancer has a prognostic impact: a single-institution analysis. Ann Oncol. 2013;24(1):p. 101-8. doi:10.1093/annonc/mds248

4. Matsumoto A, Jinno H, Murata T, et al. Prognostic implications of receptor discordance between primary and recurrent breast cancer. Int J Clin Oncol. 2015;20(4):701-8. doi:10.1007/s10147-014-0759-2

5. Lower EE, Khan S, Kennedy D, et al. Discordance of the estrogen receptor and HER-2/neu in breast cancer from primary lesion to first and second metastatic site. Breast Cancer (Dove Med Press). 2017;9:515-520. doi:10.2147/BCTT.S137709
6. Yuda S, Shimizu C, Yoshida M, et al. Biomarker discordance between primary breast cancer and bone or bone marrow metastases. Jpn J Clin Oncol. 2019;49(5):426-430. doi:10.1093/jjco/hyz018

7. Yeung C, Hilton J, Clemons M, et al. Estrogen, progesterone, and HER2/neu receptor discordance between primary and metastatic breast tumours-a review. Cancer Metastasis Rev. 2016;35 (3):427-437. doi:10.1007/s10555-016-9631-3

8. Erdem GU, Altundag K, Ozdemir NY, et al. Comparative study of receptor discordance between primary and corresponding metastatic lesions in breast cancer. $J$ BUON. 2017;22(2):365-376.

9. Ilgun S, Sarsenov D, Erdogan Z, et al. Receptor discordance rate and its effects on survival in primary and recurrent breast cancer patients. J BUON. 2016;21(6):1425-1432.

10. Nogami T, Shien T, Tanaka T, et al. The discordance between primary breast cancer lesions and pulmonary metastatic lesions in expression of aldehyde dehydrogenase 1-positive cancer cells. Breast Cancer. 2014;21(6):698-702. doi:10.1007/s12282-013-0445-7

11. Moussa O, Purdie C, Vinnicombe S, et al. Biomarker discordance: prospective and retrospective evidence that biopsy of recurrent disease is of clinical utility. Cancer Biomark. 2012;12(6):231-239. doi:10.3233/CBM-130314

12. Liedtke C, Broglio K, Moulder S, et al. Prognostic impact of discordance between triple-receptor measurements in primary and recurrent breast cancer. Ann Oncol. 2009;20(12):1953-1958. doi:10.1093/ annonc/mdp263

13. Ataseven B, Gologan D, Gunesch A, et al. HER2/neu, topoisomerase $2 \mathrm{~A}$, estrogen and progesterone receptors: discordance between primary breast cancer and metastatic axillary lymph node in expression and amplification characteristics. Breast Care (Basel). 2012;7 (6):465-470. doi:10.1159/000345467

14. Aurilio G, Disalvatore D, Pruneri G, et al. A meta-analysis of oestrogen receptor, progesterone receptor and human epidermal growth factor receptor 2 discordance between primary breast cancer and metastases. Eur J Cancer. 2014;50(2):277-289. doi:10.1016/j.ejca.2013.10.004

15. Sighoko D, Liu J, Hou N, et al. Discordance in hormone receptor status among primary, metastatic, and second primary breast cancers: biological difference or misclassification? Oncologist. 2014;19 (6):592-601. doi:10.1634/theoncologist.2013-0427

16. Viale G, Slaets L, de Snoo FA, et al. Discordant assessment of tumor biomarkers by histopathological and molecular assays in the EORTC randomized controlled 10041/BIG 03-04 MINDACT trial breast cancer: intratumoral heterogeneity and DCIS or normal tissue components are unlikely to be the cause of discordance. Breast Cancer Res Treat. 2016;155(3):463-469. doi:10.1007/s10549-016-3690-6

17. Anand AS, Velayudhan ST. Discordance of estrogen \& progesterone receptors after neoadjuvant chemotherapy in breast cancer- an Indian Study. Indian J Surg Oncol. 2016;7(3):316-319. doi:10.1007/s13193016-0515-3

18. Timmer M, Werner J-M, Röhn G, et al. Discordance and conversion rates of progesterone-, estrogen-, and HER2/neu-receptor status in primary breast cancer and brain metastasis mainly triggered by hormone therapy. Anticancer Res. 2017;37(9):4859-4865. doi:10.21873/ anticanres. 11894

19. Heitz F, Barinoff J, Du Bois O, et al. Differences in the receptor status between primary and recurrent breast cancer-the frequency of and the reasons for discordance. Oncology. 2013;84(6):319-325. doi:10.1159/000346184

20. Basak Oven Ustaalioglu B, Aker Vardar F, Bilici A, et al. Clinical importance of discordance of hormone receptors and Her2/neu status after neoadjuvant chemotherapy in breast cancer. $J$ BUON. 2014;19 (4):879-886.

21. Nishimura R, Osako T, Okumura Y, Tashima R, Toyozumi Y, Arima N. Changes in the ER, PgR, HER2, p53 and Ki-67 biological markers between primary and recurrent breast cancer: discordance rates and prognosis. World J Surg Oncol. 2011;9:131. doi:10.1186/ $1477-7819-9-131$ 
22. Matsumoto A, Jinno H, Murata T, et al. Prognostic implications of receptor discordance between primary and recurrent breast cancer. Int J Clin Oncol. 2015;20:701-708. doi:10.1007/s10147-014-0759-2

23. Chang J, Clark GM, Allred DC, et al. Survival of patients with metastatic breast carcinoma: importance of prognostic markers of the primary tumor Cancer. 2003;97(3):545-553. doi:10.1002/(ISSN)1097-0142

24. Shiino S, Kinoshita T, Yoshida M, et al. Prognostic impact of discordance in hormone receptor status between primary and recurrent sites in patients with recurrent breast cancer. Clin Breast Cancer. 2016;16(4):e133-e140. S1526820916301100.

25. Kinoe H, Barresi V, Caltabiano R, et al. Discordance of hormone receptor, human epidermal growth factor receptor-2, and $\mathrm{Ki}-67$ between primary breast cancer and synchronous axillary lymph node metastasis. J BUON. 2018;23(7):60-66.
26. Manson QF, Schrijver WAME, Ter Hoeve ND, et al. Frequent discordance in PD-1 and PD-L1 expression between primary breast tumors and their matched distant metastases. Clin Exp Metastasis. 2019;36(1):29-37. doi:10.1007/s10585-018-9950-6

27. Van Poznak C, Somerfield MR, Bast RC, et al. Use of biomarkers to guide decisions on systemic therapy for women with metastatic breast cancer: American Society of Clinical Oncology clinical practice guideline. J Clin Oncol. 2015;33(24):2695-2704. doi:10.1200/ JCO.2015.61.1459

28. Vogel C, MALTER W, MORGENSTERN B, et al. The role of previous therapies and sites of metastasis as influencing factors on discordance of ER, PR and HER2 status between primary and metastasized breast cancer. Anticancer Res. 2019;39(5):2647-2659. doi:10.21873/anticanres.13389

\section{Publish your work in this journal}

OncoTargets and Therapy is an international, peer-reviewed, open access journal focusing on the pathological basis of all cancers, potential targets for therapy and treatment protocols employed to improve the management of cancer patients. The journal also focuses on the impact of management programs and new therapeutic agents and protocols on patient perspectives such as quality of life, adherence and satisfaction. The manuscript management system is completely online and includes a very quick and fair peer-review system, which is all easy to use. Visit http://www.dovepress.com/ testimonials.php to read real quotes from published authors. 